\title{
Influence of Raw Milk Quality on Fluid Milk Shelf Life ${ }^{1,2}$
}

\author{
D. M. Barbano, ${ }^{\star 3}$ Y. Ma, $\dagger$ and M. V. Santosł \\ *Northeast Dairy Foods Research Center, Department of Food Science, Cornell University, Ithaca, NY 14853 \\ †Kraft, Inc., Glenview, IL 60025 \\ ‡Departamento de Nutrição e Produção Animal, Faculdade de Medicina Veterinária e Zootecnia, \\ Universidade de São Paulo, Pirassununga, SP, Brazil
}

\begin{abstract}
Pasteurized fluid milk shelf life is influenced by raw milk quality. The microbial count and somatic cell count (SCC) determine the load of heat-resistant enzymes in milk. Generally, high levels of psychrotrophic bacteria in raw milk are required to contribute sufficient quantities of heat-stable proteases and lipases to cause breakdown of protein and fat after pasteurization. Sanitation, refrigeration, and the addition of $\mathrm{CO}_{2}$ to milk are used to control both total and psychrotrophic bacteria count. It is not uncommon for total bacterial counts of raw milk to be $<10,000 \mathrm{cfu} / \mathrm{mL}$. In the past, fluid milk processors have not focused much attention on milk SCC. Increased SCC is correlated with increased amounts of heat-stable protease (plasmin) and lipase (lipoprotein lipase) in milk. When starting with raw milk that has a low bacterial count, and in the absence of microbial growth in pasteurized milk, enzymes associated with high SCC will cause protein and fat degradation during refrigerated storage, and produce off-flavors. As the ability to kill, remove, or control microbial growth in pasteurized refrigerated milk continues to improve, the original milk SCC will be the factor limiting the time of refrigerated storage before development of an offflavor in milk. Most healthy cows in a dairy herd have a milk SCC $<50,000$ cell $/ \mathrm{mL}$. Bulk tank SCC $>200,000$ cell $/ \mathrm{mL}$ are usually due to the contribution of high SCC milk from a small number of cows in the herd. Technology to identify these cows and keep their milk out of the bulk tank could substantially increase the value of the remaining milk for use in fluid milk processing. To achieve a 60- to 90-d shelf life of refrigerated fluid milk, fluid processors and dairy farmers need to work together to structure economic incentives that allow farm-
\end{abstract}

Received November 25, 2005.

Accepted January 13, 2006.

${ }^{1}$ Presented at the ADSA/ASAS/CSAS Joint Annual Meeting, Cincinnati, OH, July 2005.

${ }^{2}$ Use of names, names of ingredients, and identification of specific models of equipment is for scientific clarity and does not constitute any endorsement of product by authors, Cornell University, or the Northeast Dairy Foods Research Center.

${ }^{3}$ Corresponding author: dmb37@cornell.edu ers to produce milk with the SCC needed for extended refrigerated shelf life.

Key words: shelf life, somatic cell count, proteolysis, flavor

\section{INTRODUCTION}

The Pasteurized Milk Ordinance (PMO) requires that total bacteria count in Grade A milk leaving the farm is $<100,000 \mathrm{cfu} / \mathrm{mL}$ and that the total bacterial count in commingled milk at the processing plant is $<300,000 \mathrm{cfu} / \mathrm{mL}$. Most milk in the United States has much lower counts than these requirements. The PMO also requires that the SCC of Grade A raw milk be $<750,000$ cells $/ \mathrm{mL}$. The PMO requirements for maximum bacteria and SCC are to ensure public health and are not intended as dairy product quality standards. During the mid-1970s and 1990s, raw milk quality payment incentive programs became common, particularly among cheese makers (Barbano, 1992). Adverse effects of using high SCC milk for cheese making include reduced curd firmness (Politis and Ng-Kwai-Hang, 1988a), decreased cheese yield (Politis and Ng-KwaiHang, 1988b; Barbano et al., 1991; Klei et al., 1998), increased fat and casein loss in whey (Politis and NgKwai-Hang, 1988b), and compromised sensory quality (Munro et al., 1984). For these reasons, the cheese industry has provided dairy farmers premium quality payments to encourage reduced raw milk SCC. Before the incorporation of protein into the regulated milk payment system, protein was also a common bonus payment item in milk quality payment incentive programs by cheese makers. Milk quality payment incentive programs typically have multiple criteria, such as no detectable antibiotic and added water, total bacteria count $<25,000 \mathrm{cfu} / \mathrm{mL}$, laboratory pasteurized count $<500 \mathrm{cfu} /$ $\mathrm{mL}$, low sediment test (e.g., 1 or 2), and low SCC, usually $<300,000$ cells $/ \mathrm{mL}$. Generally, the amount of the bonus payment was increased as milk SCC was decreased. These milk quality payment bonus programs were very popular among farmers and ultimately were offered by almost all cheese makers. In January 2000 , at the request of the dairy industry, several USDA Federal 
Milk Market Orders incorporated milk protein and SCC as part of the regulated milk payment system.

The fluid milk industry has been reluctant to initiate similar quality bonus payment programs as those paid by cheese makers. Compared with research on the impact of milk SCC on cheese yield, there is very little published quantitative data correlating raw milk SCC, particularly very low SCC, to flavor quality of pasteurized fluid milk. Today, the typical refrigerated fluid milk shelf life for HTST milk in the United States is about $14 \mathrm{~d}$ (Boor, 2001). In these HTST milks, shelf life is typically limited by the growth of psychrotrophic bacteria and production of off-flavors associated with this microbial growth. The use of higher than minimum HTST pasteurization conditions (e.g., $78^{\circ} \mathrm{C}$ for 16 to 30 s) by commercial fluid milk processors (Douglas et al., 2000) combined with better filler and packaging technology has increased microbial kill, reduced postpasteurization contamination, and allowed some plants to achieve 15 to $25 \mathrm{~d}$ of refrigerated shelf life. After $17 \mathrm{~d}$ of refrigerated storage in these milks, gram-positive spore-formers have been found to be the predominant cause of microbial spoilage of HTST milk when refrigerated shelf life is $>17 \mathrm{~d}$ (Fromm and Boor, 2004). Fluid milk processors would like to achieve 60 to $90 \mathrm{~d}$ of refrigerated shelf life for HTST milk to allow more efficient marketing and distribution of product. Ultrapasteurization is one approach to do this but consumers, particularly young children, clearly do not like the heatinduced off-flavors associated with high heat treatments and would prefer HTST milk (Chapman and Boor, 2001). As alternative nonthermal technologies (e.g., microfiltration) continue to develop the possibility of longer fluid milk shelf life of HTST milk, the question of what quality of raw milk will be required to achieve a 60- to 90-d shelf life becomes more important and will be addressed in this paper.

\section{RAW MILK QUALITY AND FLUID MILK SHELF LIFE}

\section{Influence of Bacteria}

Enclosed pipeline milk systems, better sanitary design of equipment, cleaner cows, and more effective "clean in place" systems have provided the opportunity for farms to produce raw milk with less microbial contamination. Rapid cooling of raw milk before the bulk tank with inline plate coolers has reduced the growth of contaminating bacteria. Rapid cooling and refrigerated storage of raw milk has favored the growth of psychrotrophic bacteria in raw milk. Nonspore-forming psychrotrophic bacteria, particularly Pseudomonas spp., are killed by HTST pasteurization. Pseudomonas spp. would need to grow to relatively high numbers (e.g., 1 $\times 10^{6}$ ) in raw milk before pasteurization to produce an off-flavor directly. Psychrotrophic gram-negative bacteria produce heat-stable proteases and lipases, and a high level of these organisms in raw milk could contribute heat-stable enzymes that may produce off-flavor issues later during the shelf life of pasteurized milk. However, if the raw milk used for fluid milk processing conforms to the Grade A total bacteria count standards in the PMO, then raw milk psychrotrophic bacteria count should not be a problem in a good quality milk supply today. Postpasteurization contamination of milk with psychrotrophic gram-negative bacteria has typically limited shelf life of conventionally pasteurized milk to 14 to $17 \mathrm{~d}$. Today, improved postpasteurization milk handling and packaging conditions have eliminated the gram-negative spoilage problem, and has revealed the presence of a smaller number of heat-resistant psychrotrophic gram-positive bacteria such as $\mathrm{Ba}$ cillus spp. and Microbacter (Ralyea et al., 1998; Fromm and Boor, 2004). Elimination of gram-positive psychrotrophic spoilage organisms is the next hurdle to extending the shelf life of HTST-pasteurized fluid milk. However, it is not clear if the gram-positive psychrotrophic spoilage organisms come from heat-resistant bacteria in biofilms present in bulk tanks in the raw milk supply or from the processing plant.

\section{Influence of Spores}

Spores can get into the milk at the farm, and present a much more difficult problem for fluid milk shelf life than vegetative bacterial cells. The sediment test is a crude indication of the potential load of spore formers in raw milk; a laboratory pasteurized bacteria count is a much better indication of the level of spore formers in raw milk.

For this reason, these 2 tests are often used as a criterion in raw milk quality improvement programs. Spores are typically present in low numbers in raw milk but they can survive HTST pasteurization, even at temperatures well above minimum pasteurization (e.g., $78^{\circ} \mathrm{C}$ for 15 to $30 \mathrm{~s}$ ). Fluid milk that has been HTST-pasteurized and that achieves a shelf life of $14 \mathrm{~d}$ with $<20,000 \mathrm{cfu} / \mathrm{mL}$ total bacteria count will generally spoil by 25 to $30 \mathrm{~d}$ because of the growth of sporeformers. Fromm and Boor (2004) reported that these gram-positive spore-formers in HTST fluid milk were predominantly Paenibacillus and Bacillus species. Spores that originate from raw milk present a difficult challenge for achieving a long shelf life for refrigerated HTST milk and it is likely that removal of spores from raw milk by microfiltration may be a solution in the future that could be used in fluid milk processing in combination with HTST. 


\section{Influence of SCC}

Milk SCC increases when cows have mastitis. Mastitis is an inflammatory reaction within a cow's udder, commonly resulting from bacterial infection. Milk from infected cows is characterized by increased raw milk SCC. Almost all of the major and minor components in milk are affected by mastitis (Kitchen, 1981; Munro et al., 1984). Milk SCC is a commonly used indicator of the incidence of subclinical mastitis in dairy cows (National Mastitis Council, 1996). Due to the inflammatory response during mastitis, secretion of milk components that are synthesized de novo is reduced and an influx of blood components into the milk occurs (Kitchen, 1981). These blood components include a variety of hydrolytic enzymes, which alter the milk composition through the breakdown of casein and milk fat (Grieve and Kitchen, 1985). Increased proteolytic (Verdi and Barbano, 1988) and lipolytic (Azzara and Dimick, 1985a,b) activities have been reported. The primary proteolytic enzyme associated with high milk SCC is plasmin, a heat-stable), and the primary lipase is lipoprotein lipase (Azzara and Dimick, 1985b). It has been shown (Janzen, 1972; Rogers and Mitchell, 1989) that mastitis decreases the shelf life and sensory quality of pasteurized milk, due mostly to higher concentrations of FFA. However, the sensory results of these early shelf-life studies of high SCC milk were based only on sensory evaluation by a very small number of dairy judges. No data on microbial growth in milk samples were presented in these studies (Janzen, 1972; Rogers and Mitchell, 1989).

Recently, it was demonstrated that mastitis adversely affects the quality of pasteurized fluid milk by accelerating the development of sensory defects such as rancidity and bitterness (Ma et al., 2000). These defects were caused by lipolysis and proteolysis, respectively. Mean acid degree values of commingled fresh raw milks was significantly lower $(P<0.05)$ in low SCC milks $(0.27 \mathrm{mEq} / 100 \mathrm{~g}$ of fat $)$ than in high SCC milks $(0.43 \mathrm{mEq} / 100 \mathrm{~g}$ of fat $)$. The acid degree value changes in pasteurized, homogenized, $2 \%$ fat milks during $21 \mathrm{~d}$ of storage at $5^{\circ} \mathrm{C}$ for the low and high SCC milks are shown in Figure 1. The rate of acid degree value increase in high SCC milk was significantly higher $(P<$ 0.05) than that in low SCC milk. Although the milks were only evaluated over $21 \mathrm{~d}$ of storage, it would be predicted by linear regression that if microbial counts were kept low (i.e., $<20,000 \mathrm{cfu} / \mathrm{mL}$ ), then there would not be an off-flavor detected due to lipolysis in the low SCC milk until $68 \mathrm{~d}$ of storage (Figure 1).

During $5^{\circ} \mathrm{C}$ storage, more extensive casein degradation occurred in the high SCC milk than in low SCC milk (Figure 2). For high SCC milk samples, compared with the level at $d 1$, casein as a percentage of true

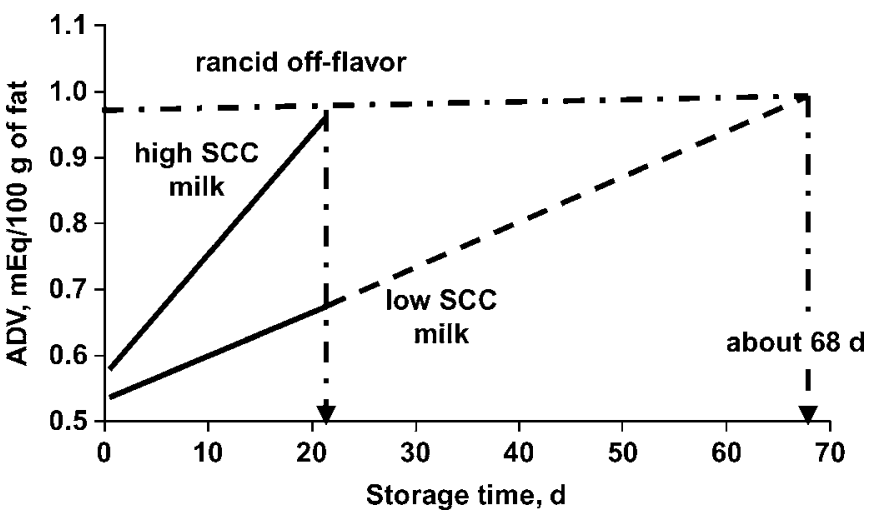

Figure 1. Acid degree values (ADV) in pasteurized, homogenized, $2 \%$ fat milks stored at $5^{\circ} \mathrm{C}$ for $1,7,14$, and $21 \mathrm{~d}$ for pasteurized milks with low and high SCC.

protein (CN\% \%P) decreased by an average of $4.04 \%$ over $21 \mathrm{~d}$ of storage. Actual levels of casein degradation were probably higher because the Kjeldahl method for nitrogen analysis may underestimate the extent of proteolysis (Verdi et al., 1987). Decreased CN\%TP during cold storage of milk, especially in high SCC milk, indicated that significant levels of proteolytic activity remained after pasteurization. High SCC raw milk has been shown to have high concentrations of plasmin, plasminogen, and proteases of somatic cell origin (Verdi et al., 1987). Plasmin is heat stable with large amounts surviving minimum pasteurization $\left(72^{\circ} \mathrm{C} / 15 \mathrm{~s}\right)$. Even after UHT treatment, 30 to $40 \%$ of plasmin activity can remain (Alichanidis et al., 1986). Other researchers have indicated that extensive proteolysis in milk can result in the accumulation of small hydrophobic peptides, causing bitterness (Rouseff, 1990) and astringency (Lemieux and Simard, 1994). The high SCC milk had significantly higher scores for bitter and astringent

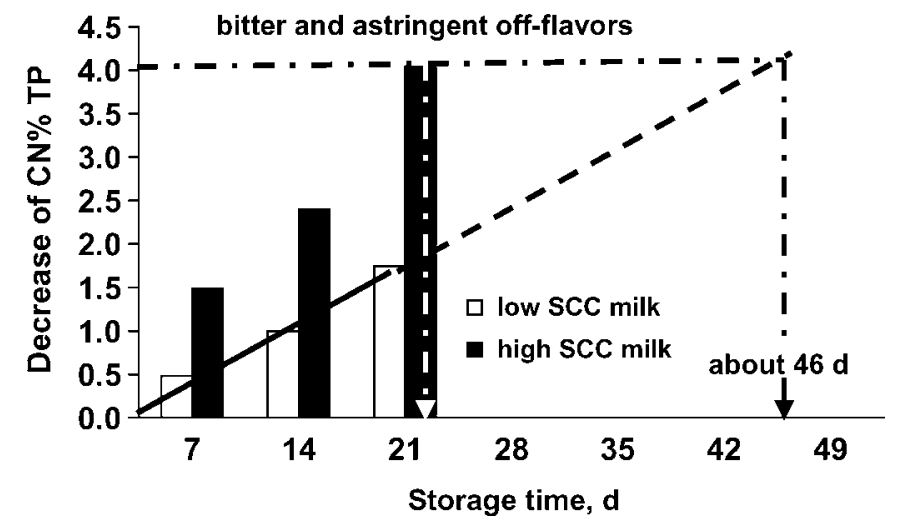

Figure 2. Average decreases in casein as a percentage of true protein $(\mathrm{CN} \% \mathrm{TP})$ in pasteurized low and high SCC milks during a 21-d refrigerated storage period. 


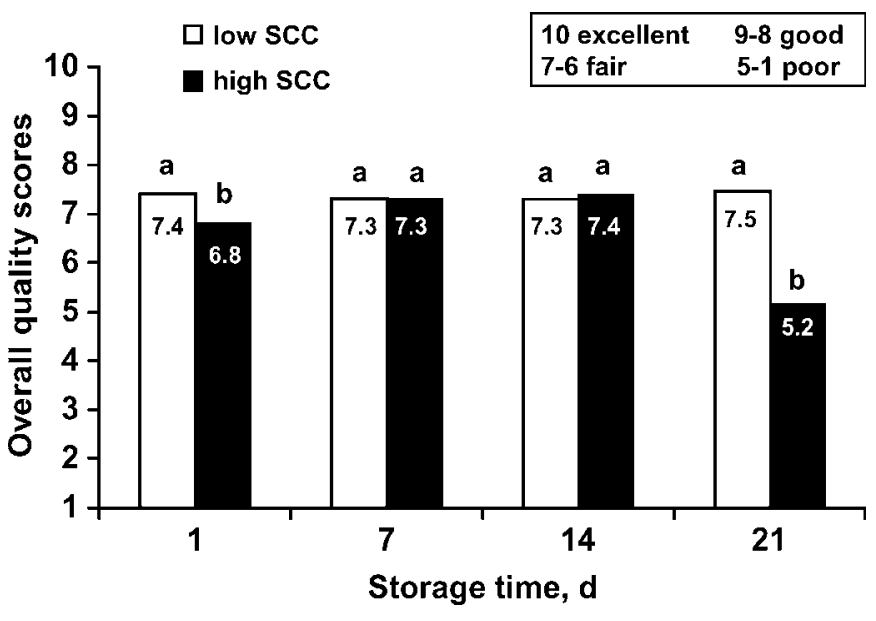

Figure 3. Mean overall quality rating for pasteurized, homogenized, $2 \%$ fat milk stored at $5^{\circ} \mathrm{C}$ for $1,7,14$, and $21 \mathrm{~d}$ for low and high SCC milk. ${ }^{\text {a,b }}$ Mean sensory scores within the same storage day with different superscript letters differ. LSD (one sided, $\alpha=0.05$ ) used for mean separation is 0.520 .

flavors at $21 \mathrm{~d}$ than did low SCC milks. Although bitterness is rarely a problem associated with pasteurized milk over $14 \mathrm{~d}$ of shelf life, it can be a problem when levels of heat-resistant plasmin are high, as is the case during mastitis (Rouseff, 1990). Although the milks were only evaluated for $21 \mathrm{~d}$ of storage, it would be predicted by linear regression that if microbial counts were kept low (i.e., $<20,000 \mathrm{cfu} / \mathrm{mL}$ ), then there would not be an off-flavor detected due to proteolysis in the low SCC milk until $46 \mathrm{~d}$ of storage (Figure 2). Comparison of extrapolations in Figure 1 and 2 indicate that proteolysis due to plasmin would produce an off-flavor earlier during shelf life in extended shelf-life refrigerated fluid milks than lipolysis due to lipoprotein lipase associated with high milk SCC (Ma et al., 2000). The overall flavor scores for the low SCC, $2 \%$ pasteurized homogenized milks did not change over $21 \mathrm{~d}$ of storage at $5^{\circ} \mathrm{C}$, which is remarkable, whereas overall flavor score for high SCC, $2 \%$ pasteurized homogenized milk decreased significantly between d 14 and 21 of refrigerated storage (Figure 3). The study of Ma et al. (2000) demonstrated the potential for pasteurized low SCC milk to achieve much longer refrigerated shelf life than high SCC milk when bacteria count is kept low.

The results of the work of $\mathrm{Ma}$ et al. (2000) left the question of how much longer the refrigerated shelf life of fluid milk could be, if raw milk SCC were kept low and microbial growth in pasteurized milk was controlled. A study by Santos et al. (2003b) addressed this issue. Santos et al. (2003a) carried out a study to correlate chemical indices of lipolysis and proteolysis in fluid milk to the sensory threshold for detection of off-flavor and determined that a rancid off-flavor can be detected in

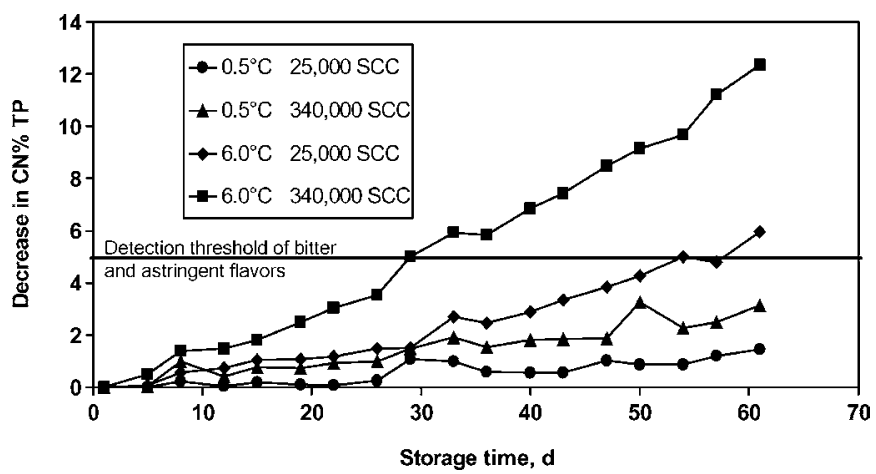

Figure 4. Increase in casein as a percentage of true protein (CN\%TP) for preserved pasteurized $2 \%$ fat milks that were produced from raw milks that contained 25,000 and $340,000 \mathrm{SCC} / \mathrm{mL}$ and were stored at 0.5 and $6^{\circ} \mathrm{C}$. [From Santos et al., 2003b; reproduced with permission.]

$2 \%$ milk due to lipolysis at a level of $0.33 \mathrm{mEq}$ of FFA/ $\mathrm{kg}$ of milk, whereas a decrease of $4.76 \%$ in CN\%TP would cause detection of bitter and astringent off-flavors in skim milk. These chemical indicators of sensory threshold values for lipolysis and proteolysis were then used in a follow-up study (Santos et al., 2003b) to determine the influence of raw milk SCC and pasteurized milk storage temperature on lipolysis and proteolysis. Santos et al. (2003b) found that off-flavor thresholds due to proteolysis related to increased raw milk SCC were reached sooner during refrigerated storage than sensory thresholds for lipolysis with increasing milk SCC when microbial growth was blocked. Both raw milk SCC and temperature of refrigerated storage were very important determinants of how fast proteolysis would occur during storage and when the sensory threshold for an off-flavor would be reached (Figure 4). At a storage temperature of $6^{\circ} \mathrm{C}$, raw milk with an SCC of 340,000 cells $/ \mathrm{mL}$ would be expected to have a detectable off-flavor at $28 \mathrm{~d}$ even if the milk bacterial count was $<20,000 \mathrm{cfu} / \mathrm{mL}$, whereas a pasteurized $2 \%$ milk that originally had an SCC of 25,000 cells $/ \mathrm{mL}$ would not be expected to have an off-flavor due to proteolysis until about $55 \mathrm{~d}$ (Figure 4 ). At $0.5^{\circ} \mathrm{C}$, the rate of proteolysis and off-flavor development due to proteolysis is much slower, and the low and high SCC milks would not develop an off-flavor due to proteolysis until after $100 \mathrm{~d}$ of storage at $0.5^{\circ} \mathrm{C}$ (Figure 4). These findings demonstrated the importance of milk storage temperature during shelf life and data for storage temperatures between 6 and $0.5^{\circ} \mathrm{C}$ were reported (Santos et al., $2003 \mathrm{~b})$. The reduction in proteolysis with decreasing temperature was not linear and efforts to control milk temperature during storage are important in controlling lipolytic and proteolytic enzyme activity that survives pasteurization. If milk bacterial count of pasteur- 
ized milk is kept low by use of other technologies such as microfiltration, then the original SCC of the raw milk becomes the critical factor in maintaining flavor quality of refrigerated fluid milk.

\section{CONCLUSIONS}

If the raw milk bacterial count is $<25,000 \mathrm{cfu} / \mathrm{mL}$, then the raw milk SCC will be the most important determinant of shelf life in pasteurized extended shelflife milk with respect to development of off-flavors when postpasteurization bacterial growth is controlled (i.e., $<500,000 \mathrm{cfu} / \mathrm{mL}$ ). The influence of raw milk SCC on pasteurized fluid milk quality is caused by increasing levels of heat-stable proteases and lipases originating from the cow with increasing milk SCC. As the combination of nonthermal technologies (e.g., microfiltration) reduce the initial bacterial and spore counts of pasteurized milk to very low levels, better filling and packaging technologies limit postpasteurization contamination, and control of refrigeration temperatures during marketing and distribution improve and allow milk to have low bacterial counts for 60 to $90 \mathrm{~d}$, then the activity of proteolytic and lipolytic enzymes originating from the cow will be the limiting factor in maintaining the flavor quality of fluid milk. A raw milk SCC of 100,000 cell/mL should be achievable at the farm level with appropriate financial incentives for producers. High-quality, lowSCC raw milk is a critical part of producing HTST milk with a shelf life of 30 to $90 \mathrm{~d}$.

\section{REFERENCES}

Alichanidis, E., J. H. M. Wrathall, and A. T. Andrews. 1986. Heat stability of plasmin (milk protease) and plasminogen. J. Dairy Res. 53:259-269.

Azzara, C. D., and P. S. Dimick. 1985a. Lipolytic enzymes activity of macrophages in bovine mammary gland secretions. J. Dairy Sci. 68:1804-1812.

Azzara, C. D., and P. S. Dimick. 1985b. Lipoprotein lipase activity of milk from cows with prolonged subclinical mastitis. J. Dairy Sci. 68:3171-3175.

Barbano, D. M. 1992. Raw milk quality: Milk quality improvement in the United States. Aust. J. Dairy Technol. 47:89-90.

Barbano, D. M., R. R. Rasmussen, and J. M. Lynch. 1991. Influence of milk somatic cell count and milk age on cheese yield. J. Dairy Sci. 74:369-388.

Boor, K. J. 2001. Fluid dairy product quality and safety: Looking to the future. J. Dairy Sci. 84:1-11.

Chapman, K. W., and K. J. Boor. 2001. Acceptance of 2\% ultrapasteurized milk by consumers, 6 to 11 years old. J. Dairy Sci. 84:951-954.
Douglas, S. A., M. J. Gray, A. D. Crandall, and K. J. Boor. 2000. Characterization of chocolate milk spoilage patterns. J. Food Prot. 63:516-521.

Fromm, H. I., and K. J. Boor. 2004. Characterization of pasteurized fluid milk shelf life attributes. J. Food Sci. 69:M207-M213.

Grieve, P. A., and B. J. Kitchen. 1985. Proteolysis in milk: The significance of proteinases originating from milk leucocytes and a comparison of the action of leucocyte, bacterial and natural milk proteinases on casein. J. Dairy Res. 52:101-112.

Janzen, J. J. 1972. The effect of somatic cell concentration in the raw milk on the shelf-life of the processed product. J. Milk Food Technol. 35:112-114.

Kitchen, B. J. 1981. Review of the progress of dairy science: Bovine mastitis: Milk compositional changes and related diagnostic tests. J. Dairy Res. 48:167-188.

Klei, L., J. Yun, A. Sapru, J. Lynch, D. Barbano, P. Sears, and D. Galton. 1998. Effects of milk somatic cell count on cottage cheese yield and quality. J. Dairy Sci. 81:1205-1213.

Lemieux, L., and R. E. Simard. 1994. Astringency, a textural defect in dairy products. Lait 74:217-240.

Ma, Y., C. Ryan, D. M. Barbano, D. M. Galton, M. Rudan, and K. Boor. 2000. Effects of somatic cell count on quality and shelf-life of pasteurized fluid milk. J. Dairy Sci. 83:264-274.

Munro, G. L., P. A. Grieve, and B. J. Kitchen. 1984. Effects of mastitis on milk yield, milk composition, processing properties and yield and quality of milk products. Aust. J. Dairy Technol. 39:7-16.

National Mastitis Council. 1996. Current concepts of bovine mastitis. 4th ed. National Mastitis Counc., Madison, WI.

Politis, I., and K. F. Ng-Kwai-Hang. 1988a. Effects of somatic cell counts and milk composition on cheese composition and coagulating properties of milk. J. Dairy Sci. 71:1711-1719.

Politis, I., and K. F. Ng-Kwai-Hang. 1988b. Association between somatic cell counts of milk and cheese yielding capacity. J. Dairy Sci. 71:1720-1727.

Ralyea, R., W. Weidmann, and K. J. Boor. 1998. Bacterial tracking in a dairy production system using phenotypic and ribotyping methods. J. Food Prot. 61:1336-1340.

Rogers, S. A., and G. E. Mitchell. 1989. The relationship between somatic cell count, composition and manufacturing properties of bulk milk 5. Pasteurized milk and skim milk powder. Aust. J. Dairy Technol. 44:57-60.

Rouseff, R. L. 1990. Bitterness in food products: An overview. Page 8 in Bitterness in Foods and Beverages. R. L. Rouseff, ed. Elsevier Science Publishing Company Inc., New York, NY.

Saeman, A. I., R. J. Verdi, D. M. Galton, and D. M. Barbano. 1988. Effects of mastitis on proteolytic activity in bovine milk. J. Dairy Sci. 71:505-512.

Santos, M. V., Y. Ma, and D. M. Barbano. 2003b. Effect of somatic cell count on proteolysis and lipolysis in pasteurized fluid milk during shelf-life storage. J. Dairy Sci. 86:2491-2503.

Santos, M. V., Y. Ma, Z. Caplan, and D. M. Barbano. 2003a. Sensory threshold of off-flavors caused by proteolysis and lipolysis in milk. J. Dairy Sci. 86:1601-1607.

Schaar, J., and H. Funke. 1986. Effect of subclinical mastitis on milk plasminogen and plasmin compared with that on sodium, antitrypsin and N-acetyl- $\beta$-D-glucosaminidase. J. Dairy Res. 53:515-528.

Verdi, R. J., and D. M. Barbano. 1988. Preliminary investigation of the properties of somatic cell proteases. J. Dairy Sci. 71:534-538.

Verdi, R. J., D. M. Barbano, M. E. Dellavalle, and G. F. Senyk. 1987. Variability in true protein, casein, nonprotein nitrogen, and proteolysis in high and low somatic cell milks. J. Dairy Sci. 70:230-242. 